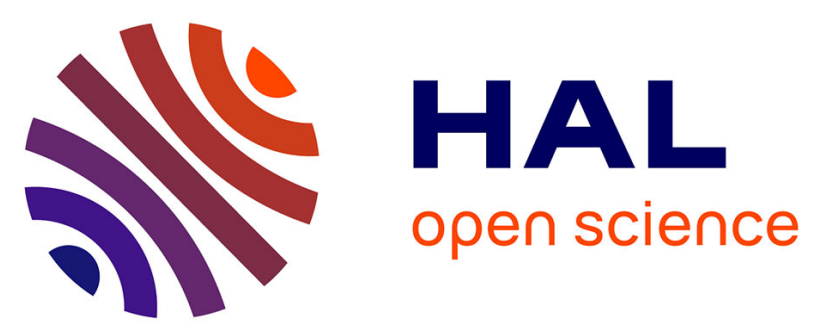

\title{
The horse mandibles at Duruthy rockshelter (Sorde-l'Abbaye, Landes, France) and the identification of ontological systems in the Pyrenean Magdalenian
}

Clément Birouste, François-Xavier Chauvière, Frédéric Fp Plassard, Morgane Dachary

\section{To cite this version:}

Clément Birouste, François-Xavier Chauvière, Frédéric Fp Plassard, Morgane Dachary. The horse mandibles at Duruthy rockshelter (Sorde-l'Abbaye, Landes, France) and the identification of ontological systems in the Pyrenean Magdalenian. Quaternary International, 2016, 414, pp.159-173. 10.1016/j.quaint.2015.12.002 . halshs-01976904

\section{HAL Id: halshs-01976904 \\ https://shs.hal.science/halshs-01976904}

Submitted on 10 Jan 2019

HAL is a multi-disciplinary open access archive for the deposit and dissemination of scientific research documents, whether they are published or not. The documents may come from teaching and research institutions in France or abroad, or from public or private research centers.
L'archive ouverte pluridisciplinaire HAL, est destinée au dépôt et à la diffusion de documents scientifiques de niveau recherche, publiés ou non, émanant des établissements d'enseignement et de recherche français ou étrangers, des laboratoires publics ou privés. 


\title{
The horse mandibles at Duruthy rockshelter (Sorde-l'Abbaye, Landes, France) and the identification of ontological systems in the Pyrenean Magdalenian
}

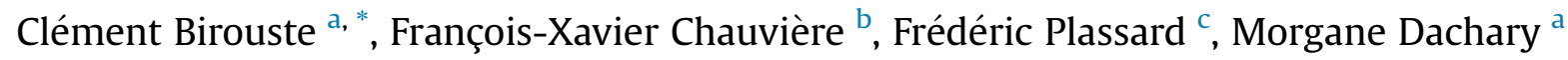 \\ a UMR 5608 TRACES, Université Toulouse Jean Jaurès, Campus Mirail, Maison de la Recherche, 5 allée A. Machado, 31058 Toulouse Cedex 9, France \\ b Office du Patrimoine et de l'archéologie de Neuchâtel - Section Archéologie, Laténium, CH-2068 Hauterive, Switzerland \\ ' UMR 5199 PACEA, Université Bordeaux 1, Avenue des facultés, FR-33400 Talence, France
}

\section{A R T I C L E I N F O}

\section{Article history:}

Available online 29 December 2015

\section{Keywords:}

Magdalenian

Pyrenees

Horse

Marks

Ontology

Animism

\begin{abstract}
A B S T R A C T
The excavations of 1961, led by Robert Arambourou in layer 4 of Duruthy rockshelter at Sorde-l'Abbaye, Landes in France, revealed an exceptional assemblage in two adjacent squares. According to the lithic and the bone industry and the radiocarbon dating, this was attributable to a late phase of the Middle Magdalenian. This assemblage included three horse sculptures in sandstone, marl limestone, and ivory, and somebody ornaments and tools made of both mineral and organic materials. A concentration of 23 horse mandible fragments found near or in direct contact with the three horse sculptures comprised a selection of bones from old horses $($ MNIc $=11)$ that had been subject to particular treatment. All the bones had scraping marks aimed at the removal of the connective tissue down to the alveolar bone, possibly to reveal the teeth entirely. On three pieces, saw marks, made with flint, and deep incisions were observed. One piece had deep grooves in an almond shape, and a mandible fragment had an engraved design on it that was unique among the geometrical designs of the Pastou group of sites. By drawing upon concepts taken from Descola's anthropology of nature, we have been able to consider the informative potential of these pieces regarding the ontology of their authors.
\end{abstract}

(C) 2015 Elsevier Ltd and INQUA. All rights reserved.

\section{Duruthy}

Amongst the different archaeological sites at Pastou cliff (Sordel'Abbaye, Landes), Duruthy rockshelter is central to our understanding of the Upper Palaeolithic in the western Pyrenees (Arambourou, 1990; Dachary, 2002, 2006, 2009, Fig. 1). From 1874, the establishment of a strong stratigraphic sequence and the abundance of human remains from prehistoric times discovered in the depths of this cave have contributed to its renown (Lartet and Chaplain-Duparc, 1874a,b,c; Henry-Gambier, 2006). The bestknown paleoanthropological assemblage (Sorde 1) consists of a skullcap and long bones, whose association with large carnivore canines, while long accepted, was only demonstrated after a recent reassessment (Chauvière, 2001). A second assemblage consists of a Holocene ossuary that topped the sedimentary sequence.

\footnotetext{
* Corresponding author.

E-mail addresses: clement.birouste@gmail.com (C. Birouste), francois-xavier chauviere@ne.ch (F.-X. Chauvière), frederic.plassard@wanadoo.fr (F. Plassard), morgane-dachary@orange.fr (M. Dachary).
}

Arambourou's excavations, conducted between 1957 and 1986, established a chronostratigraphy that encompassed middle and upper stages of the Magdalenian, the Azilian occupations, and some Chalcolithic burial practices (Arambourou, 1978; Dachary, 2002). The field operations of 1961 resulted in the discovery of some exceptional remains that permanently established the reputation of Duruthy. These included a further set of human remains (Sorde 3) and three horse sculptures attributed to the Middle Magdalenian, one of sandstone, a second made from marl limestone, and the third of ivory. These were located in a well-defined area of the rockshelter (Arambourou, 1962). The presence of such a concentration of horse mandibles, near or in direct contact with the three horse sculptures, accentuated the unusual nature of this assemblage, although it has never been published in detail (Sacchi, 1990, p. 19; Fig. 2). The opportunity to carry out an inventory of part of the Duruthy collections held at the Abbey of Arthous had made it possible to study these exceptional remains and to conduct, under the instigation of one author (FXC), a targeted examination of the horse mandibles, which had been suspected of having been subjected to unusual modification. 


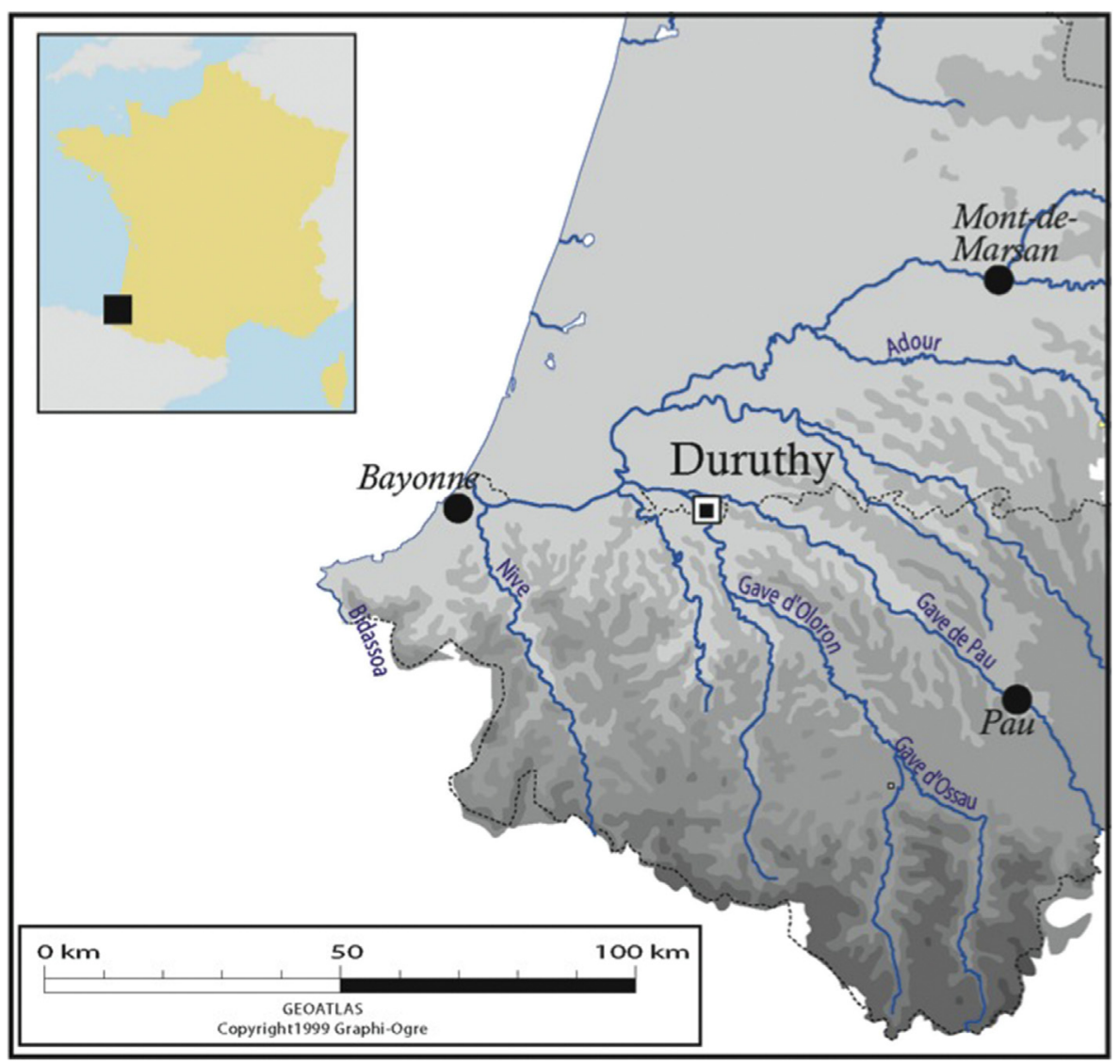

Fig. 1. Location of Duruthy.

\section{Methodology}

As well as carrying out an inventory of Arambourou's archives and applying traditional zooarchaeological methods, the concept of the chaîne opératoire (Leroi-Gourhan, 1943; Perlès, 1991) has structured the technical approach to horse mandibles presented here in order to highlight the nature and strict order of succession of the extraction, shaping, and use of the archaeological material. The mandibles, mandible fragments, and isolated teeth were observed under a binocular microscope $(\times 10)$. The zooarchaeological study concerned the remains found in squares BIII and CIII, as well as all the other horse remains, except those from the lower terrace, which are suspected of being from a mixed archaeological context (Dachary, 2002).

An estimate of the age of the horses at the time of death was carried out using the methods set out by Guadelli (1998) and Levine (1979). The data for this estimate were established according to the five age categories identified by Bignon (2003), which have the advantage of being based both on the composition of the social groups of horses and objective determination criteria:

- From 0 to 2 years, individuals are considered juveniles;

- From 2 to 5 years, sub-adults;

- From 5 to 10 years, adults in the prime of age;

- From 10 to 15 years, old adults;

- Over 15 years, very old adults.

Many authors have underlined the difficulty in defining precise ages based on the wear of horse incisors alone, particularly for horses over nine years of age (Muylle et al., 1996; Guadelli, 1998;
Bignon, 2003; Nicks et al., 2007; Muller, 2013). However, in the case of zone CIII-BIII, the ages of the horses could only be estimated according to the incisors. We therefore decided to merge the last two age categories in this study to obtain a class of "old and very old adults" aged over 10 years.

\section{The Duruthy mandibles in their archaeological context}

On several occasions, Arambourou described the 1961 discoveries at Duruthy, explaining the contextual relationship between the horse mandibles and the remains collected in a small restricted area (Fig. 3). The description he gives in his monograph on Duruthy summarizes much of what he wrote on other occasions, including in his field notes: “...This statuette [in sandstone] was lying on some horse jaw fragments, the anterior part with the incisors, six in total, lying tightly against each other. Two of them had been placed on top of each other, forming a sort of box, inside of which were two wolf premolars, perforated with a suspension hole that had in fact been broken, and a "knife" fashioned from a piece of ironstone crust (...) In the immediate vicinity was a small sagaie with a cylindrical-conical shape and a single bevel base, and a fox canine" (Arambourou, 1978, p.49). Further on he adds (p. 50) "The presence of these three sculptures in a restricted area, the representations all of the same animal, and the context surrounding the statuette near which were also found the remains of two horse skulls, is all reminiscent of a sort of sanctuary grouping together objects whose non-utilitarian nature is as evident as their symbolic value." All the remains were found in layer 4, “... a clay layer, red in colour, turning pinkish beige when wet..." (Arambourou, 1978, p. 47).

From these observations, it is possible to deduce that: 


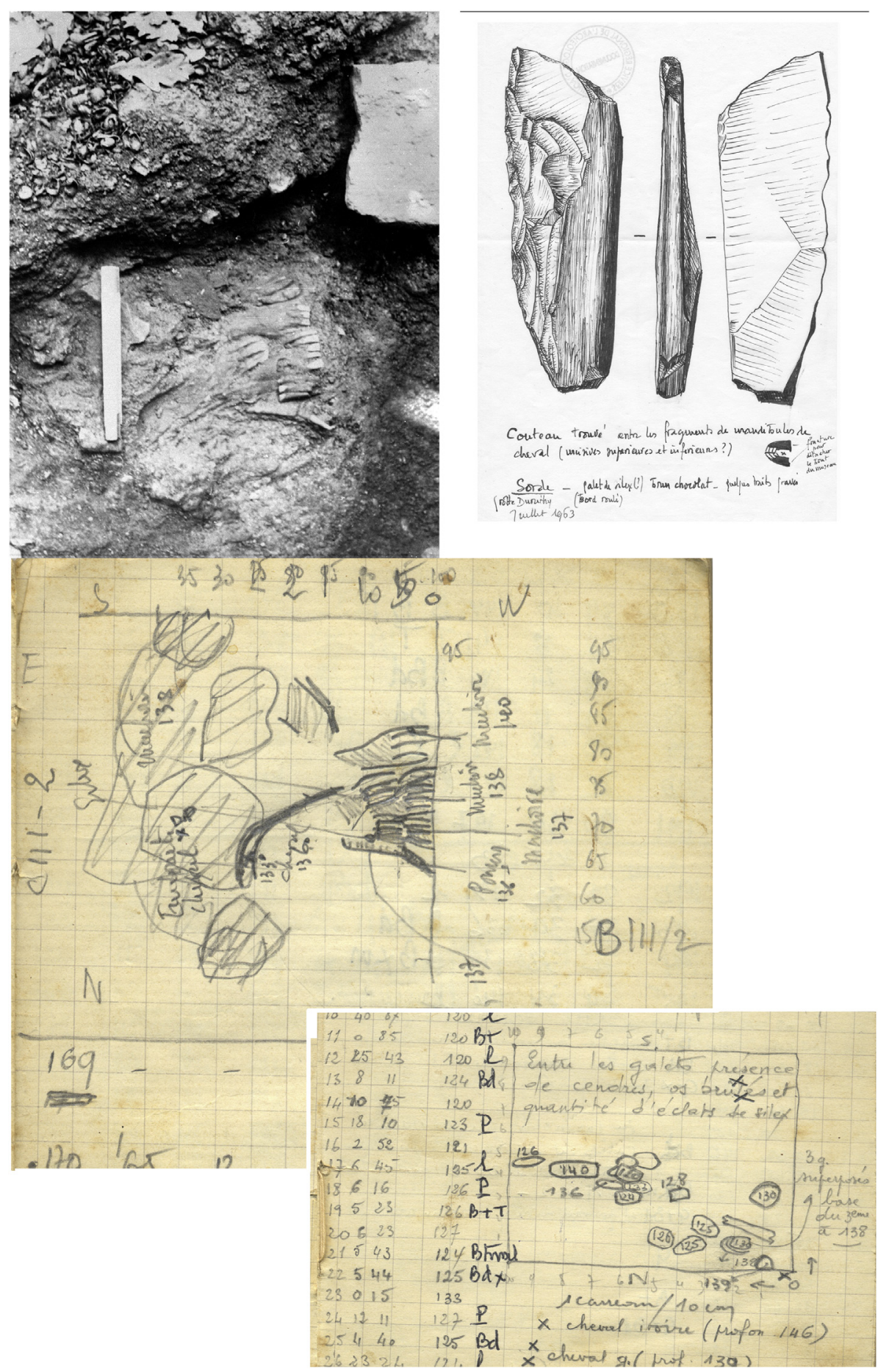

Fig. 2. Field documentation.

- The various remains are contemporary with the sedimentary envelope that contained them, in this case layer 4 . It is attributed to the Middle Magdalenian on the basis of stratigraphic interpretations, the diagnosis of the lithic and osseous remains, and radiocarbon datings (13,510 \pm 220 BP-Ly859; $14,005 \pm 65$ BP-OxA 28,118)

- These remains were found in close proximity, in two adjacent square metres (BIII and CIII) in which some of them were juxtaposed or superimposed. This arrangement further strengthens the idea of there being an association between some of the mandibles and the largest horse statuette that was found lying on top of a mandible.

On the other hand, it would seem more of a problem to establish a relationship between those elements and the human remains of "Sordes 3" recovered from the adjacent square (DIII) in 1961. First, these human remains are described as coming from the base of layer 3, overlying layer 4 (Arambourou, 1978, p. 28; Henry-Gambier, 2006). Their attribution to the final Magdalenian is based on altitudinal arguments and ${ }^{14} \mathrm{C}$ dates produced elsewhere (Arambourou 


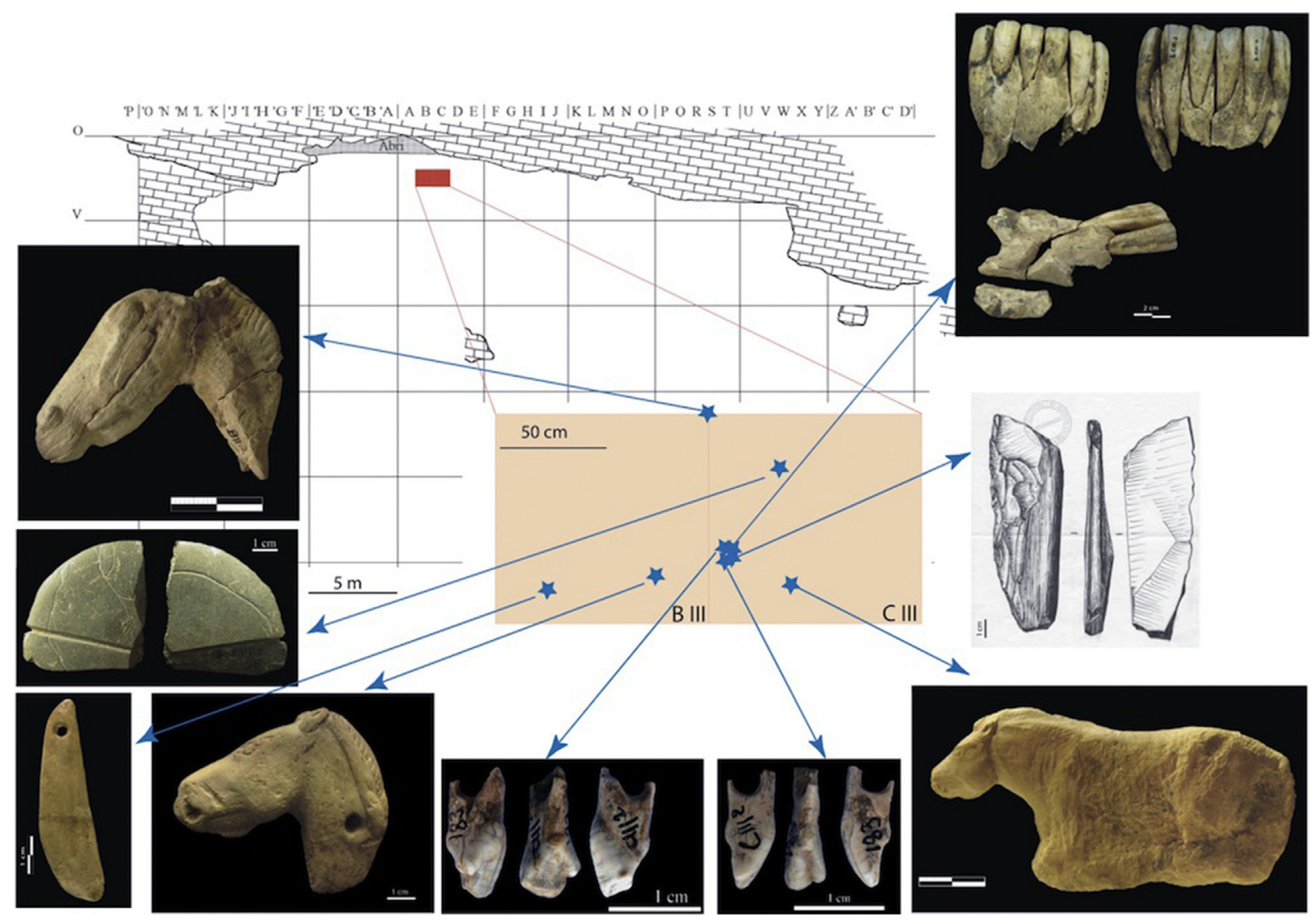

Fig. 3. Duruthy. Internal site plan.

and Genet Varcin, 1965). Second, there has been no direct dating on the Palaeolithic human remains at Duruthy. Recently, as part of the Magdatis project, the human remains found in Sorde 3 were the subject of direct dating attempts that proved unsuccessful due to the unsatisfactory levels of collagen. The skull from Sorde 1, which is the only anthropological element remaining from the 1874 discoveries, has not been dated, as heavy restoration work (varnish, adhesives, etc.) means that the bone matter may have been significantly contaminated.

This attribution to the Upper Magdalenian is questionable, however. Arambourou considers that Sorde 1 and Sorde 3 may have been contemporaneous (Arambourou and Genet-Varcin, 1965), while the engravings found on some of the large carnivore canines discovered near Sorde 1 (Chauvière, 2001; Merlet, 2007) tend to evoke the Middle Magdalenian. The accumulation of limestone debris observed above the skull may correspond to debris characteristic of a separation between layers 3 and 4 or even that reported below and against the sandstone statuette, in an anthropogenic arrangement. It is not therefore out of the question that there is a synchrony between these two Palaeolithic human skeletons and the elements of layer 4 discovered in squares BIII and CIII, but this cannot be proven and has not therefore been taken into account in the interpretation of the mandibles.

Similarly, the discovery in the DIV square in 1979, of a worked hematite fragment interpreted as a horse head is more difficult to associate with the three statuettes (Arambourou, 1980; Bahn, 1982). Both its peripheral location and the problems of interpretation incite caution.

With the exception of the two horse skulls, all the remains described in the publication and listed in the direct vicinity of the mandibles and statuettes in the excavation notebooks, have been found and identified. These remains are currently being studied and will be the subject of a later publication. The majority of the incisors and mandibles from squares CIII and BIII had already been sorted into batches when we accessed the collection. A few pieces had been consolidated with adhesives. The composition of the batches was relatively coherent: they were probably put together when the objects were collected in the field by Arambourou (Fig. 2). In most cases, the proposed reassembly of the isolated incisors as sets was accurate. These original classifications were nonetheless systematically checked to ensure that the anatomical elements had been accurately assigned, and some pieces were reattributed.

\section{Analysis}

\subsection{Skeletal elements, sex, number, and age of individuals}

The systematic sorting of the fauna associated with squares CIII and BIII has led to the discovery of some additional pieces. In total, the assemblage comprises four complete sets of six lower incisors, five partial sets of lower incisors, five mandible bone fragments, and six isolated lower incisors in CIII. In addition to this, one partial set of lower incisors, one isolated lower incisor, and one mandible bone fragment have been found in BIII (Fig. 4). The incisors are sometimes loosened and at other times still connected to the mandible bone.

The horse incisors (Equus caballus) found in this area are exclusively lower incisors. Several mandible fragments have also been identified, but no maxilla fragments.

No horse canines have been found in the area (CIII or BIII). However, this does not allow us to confirm the effective absence of canines in the individuals and to draw conclusions as to the sex of 

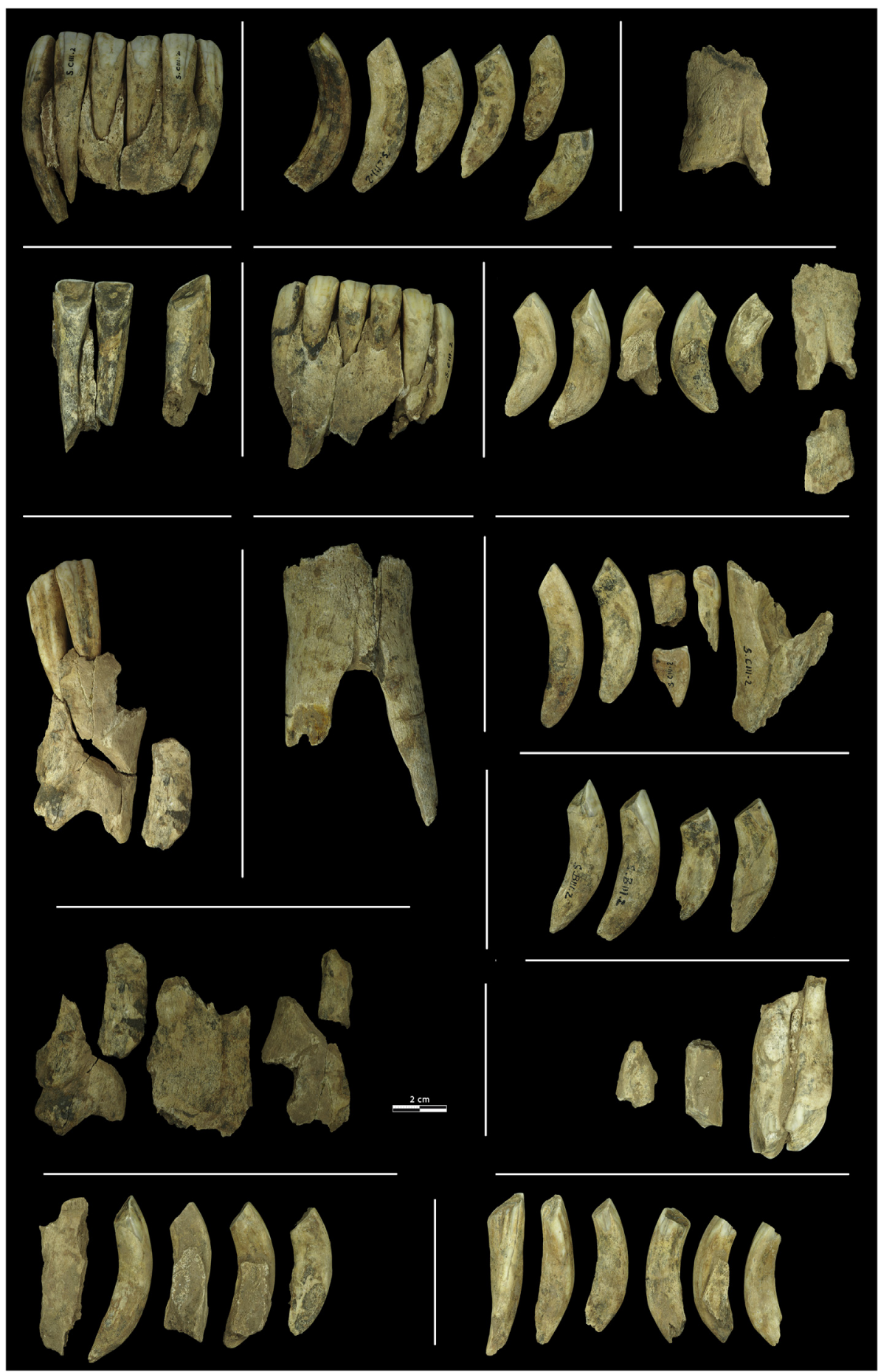

Fig. 4. The assemblage.

the individuals, as canine teeth occur more frequently in stallions than in mares. The anatomical part of the mandibles needed to confirm this is consistently absent. Nonetheless, no horse canines have been found anywhere in the collection, except on the lower terrace, where the material has not been included in the study.

There is a clear overrepresentation of horse incisors in square CIII. The majority of the horse remains in this square are lower incisors and mandibles. Of the 60 horse skeletal elements in square CIII, 47 are mandible fragments and lower incisors (Fig. 5). For this calculation, a mandible fragment with several teeth is counted as a single element. The percentage of mandibles and incisors would thus be even higher if each incisor were considered as a single entity to be counted.

The high presence of horse incisors makes this animal the dominant species in square CIII. Excluding these pieces from the calculation of the number of remains in the square would make bovines the dominant taxon, as in the rest of layer 4 . This observation highlights the exceptional nature of the horse bone assemblage in square CIII. Furthermore, the lower incisors in square CIII form the vast majority of the incisors, both lower and upper, 


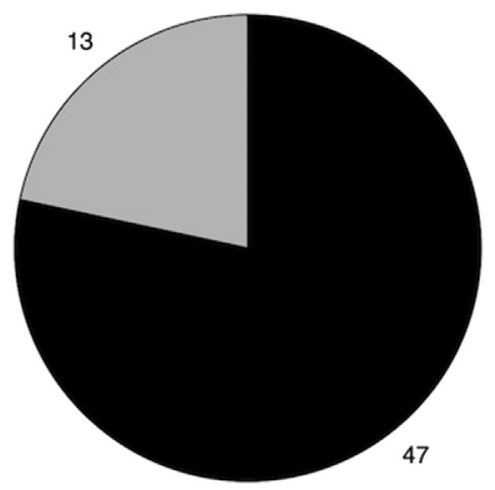

Fig. 5. Anatomical horse elements in square CIII.

present in the whole of layer 4 . Of the 65 horse incisors present in this layer (excluding the lower terrace), 49 are from square CIII.

In squares CIII and BIII, the calculation of the Minimum Number of Individuals (White, 1953) for horses based on mandible bone fragments alone yields a result of seven individuals. When this calculation is made based on both mandible fragments and incisors (in place and isolated), the MNI increases to 10 individuals. Finally, if we take into account the ages of the horses concerned to calculate an MNI by combination (Poplin, 1976), 11 individuals are counted. If this calculation of the horse MNIc is performed on the whole of layer 4 (upper terrace), 15 individuals are counted, 11 of which in squares CIII and BIII alone.

The high concentration of incisors and mandibles in zone CIII and BIII greatly contributes to the total number of horse individuals. If the same calculation is carried out on layer 4 using horse cheek teeth alone, the MNIc is reduced to 10 individuals.

The estimated age of the horses at the time of death in layer 4 indicates a majority of very old adults. However, there is also a relatively high proportion of adults and juveniles (Fig. 6). Excluding zone CIII-BIII from the calculation, it then appears that the majority of individuals are adults in the prime of age (Fig. 7). When squares CIII-BIII are considered alone, however, a large majority of the individuals present belong to the age category of old and very old adults. More specifically, this involves eight old or very old adults, two adults, no sub-adult, and one juvenile (Fig. 8). It is therefore

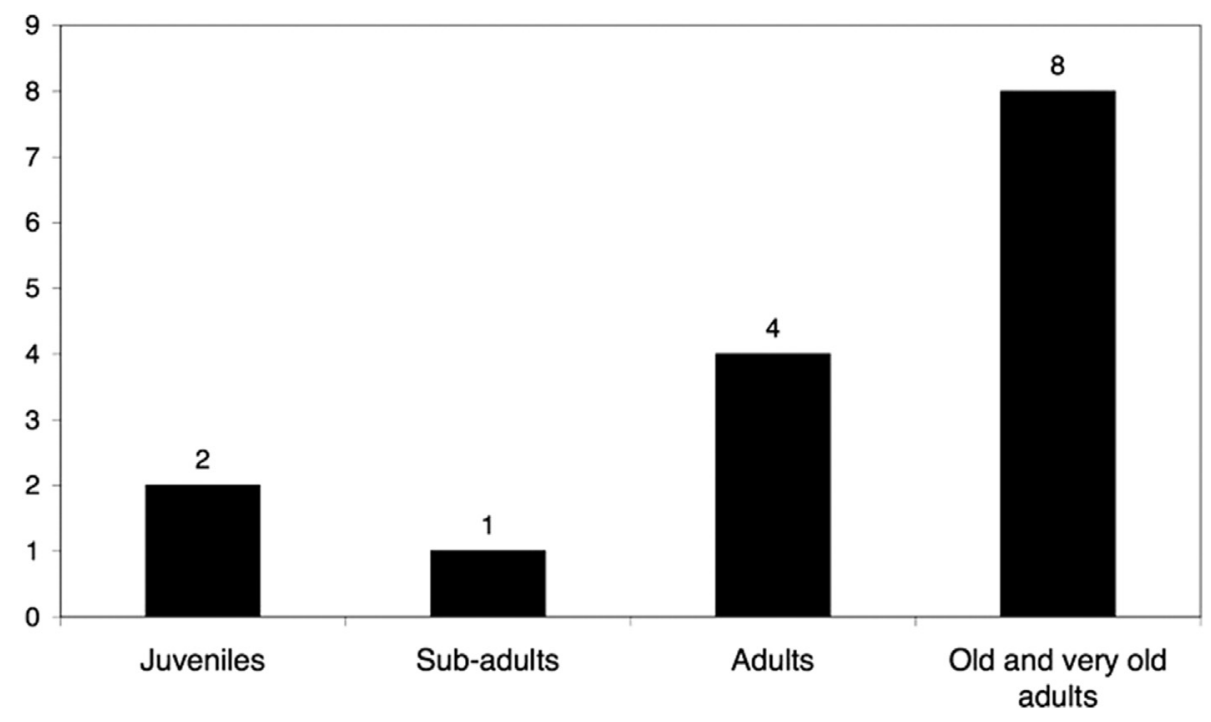

Fig. 6. Ages of individuals across layer 4 .

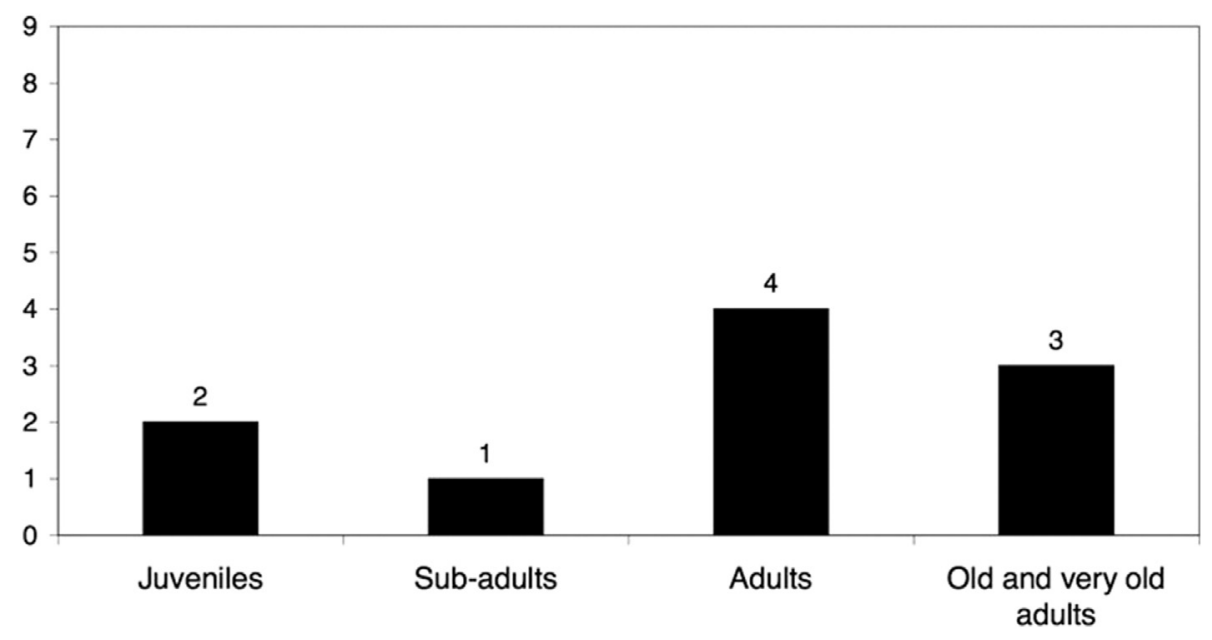

Fig. 7. Ages of individuals excluding squares CIII and BIII. 


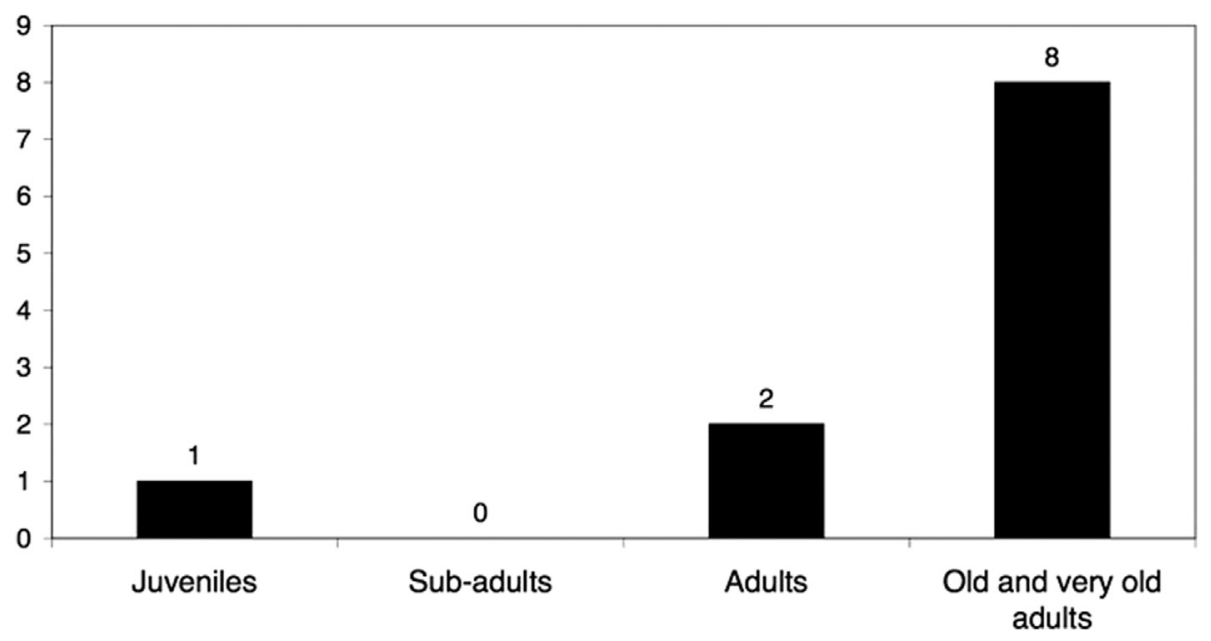

Fig. 8. Age of individuals in squares CIII and BIII.

clear that the number of individuals counted in zone CIII-BIII combined with the unique composition of ages in this zone that tilts the figures from a majority of adults in the prime of age to a majority of very old adults. Furthermore, the tooth that documents the presence of a juvenile in squares CIII-BIII is a deciduous tooth that does not correspond to any of the sets of incisors in that zone, and that does not have the characteristic marks made on the other incisors in this assemblage. It therefore appears to be intrusive to "the coherent assemblage of mandibles."

\subsection{Description of the marks}

Different types of marks are visible on the pieces: scraping, sawing, incisions, engraving, and shaping (Table 1).

The striation marks, which are observable on the buccal and lingual surfaces of the incisors, are the result of scraping with a lithic tool (Fig. 9). Sometimes deep, in a "V" shape, these marks are found on all the individuals counted in squares CIII and BIII, except the individual identified by the isolated deciduous tooth. These marks are not visible on horse incisors in the rest of the assemblage, however, nor on incisors belonging to other taxa.
The intensity of the scraping varies from one individual to another and from one tooth to another. It is not visible on all the teeth in each set, nor on both sides of each tooth. As in the case of butchery cutmarks (Lyman, 1994), the aim does not appear to have been to "make marks," but rather to perform an action that sometimes left unintentional traces.

The best preserved mandibles still have incisors in place with scraping marks. A continuity can frequently be observed in the striations across the juxtaposed teeth, both on the buccal and lingual surfaces. In these pieces, it is clear that the marks were made while the teeth were still in place in the mandibles: this is probably also the case for the teeth that are now separated from the mandible bone, as is confirmed by the absence of scraping marks on the mesial surfaces, which would not have been accessible when the teeth were in place. There are some scraping marks on the distal surfaces, but only on the third incisors, which are the only incisors whose distal faces are accessible when still attached to the mandibles.

The hypothesis that scraping marks were made during an attempt to extract the teeth from the mandible seems unlikely due to the relative shallowness of the marks on the incisors and the absence of any other kinds of marks that could confirm this action

Table 1

Characteristics of the pieces for each individual.

\begin{tabular}{|c|c|c|c|c|c|c|c|}
\hline Square & CDP inventory & $\begin{array}{l}\text { Individual (NMIc zone } \\
\text { CIII-BIII) }\end{array}$ & Age & Anatomy & Vestibular surface & Lingual surface & Connection \\
\hline BIII & $979-1-20450-1$ & 1 & Very old adult & I3R & Transverse incisions & Transverse incisions & \\
\hline BIII & $979-1-20450-2$ & 9 & Very old adult & I3R & Scraping marks & Scraping marks & \\
\hline BIII & $979-1-20450-3$ & 1 & Very old adult & I1L & Scraping marks & & \\
\hline BIII & $979-1-20450-4$ & 1 & Very old adult & $\mathrm{I} 2 \mathrm{~L}$ & Scraping marks & & \\
\hline BIII & $979-1-20460-1$ & 1 & & Bone & Transverse sawing & & \\
\hline BIII & $979-1-20460-2$ & & & Bone & Transverse sawing & $\begin{array}{l}\text { Scraping marks (shaping), } \\
\text { polished through wear? }\end{array}$ & \\
\hline CIII & 979-1-20449-nn & 3 & Old adult & I1 R & Scraping marks & & \\
\hline CIII & 979-1-20449-nn & & & $\mathrm{I} 2 \mathrm{R}$ & Scraping marks & & \\
\hline CIII & 979-1-20449-nn & & & I3R & & & \\
\hline CIII & 979-1-20449-nn & & & I1L & & & \\
\hline CIII & 979-1-20449-nn & & & $\mathrm{I} 2 \mathrm{~L}$ & & Scraping marks & \\
\hline CIII & 979-1-20449-nn & & & $\mathrm{I} 3 \mathrm{~L}$ & & Scraping marks & \\
\hline CIII & $979-1-20451-1$ & 4 & Very old adult & $\mathrm{I} 2 \mathrm{R}$ & & & \\
\hline CIII & $979-1-20451-2$ & & & I3R & & Scraping marks & \\
\hline CIII & $979-1-20451-3$ & & & I1 R & & & \\
\hline CIII & $979-1-20451-4$ & & & $\mathrm{I} 2 \mathrm{~L}$ & & & \\
\hline CIII & $979-1-20451-5$ & & & $\mathrm{I} 1 \mathrm{~L}$ & & & \\
\hline CIII & $979-1-20451-6$ & & & Bone & Scraping mark? & & \\
\hline
\end{tabular}


Table 1 (continued)

\begin{tabular}{|c|c|c|c|c|c|c|c|}
\hline Square & CDP inventory & $\begin{array}{l}\text { Individual (NMIc zone } \\
\text { CIII-BIII) }\end{array}$ & Age & Anatomy & Vestibular surface & Lingual surface & Connection \\
\hline CIII & $979-1-20451-7$ & & & Bone & & & \\
\hline CIII & $979-1-20451-8$ & & & Bone & & & \\
\hline CIII & $979-1-20452-1$ & 2 & Very old adult & $\mathrm{I} 3 \mathrm{~L}$ & Scraping marks & Scraping marks & $979-1-20456$ \\
\hline CIII & $979-1-20452-2$ & & & $\mathrm{I} 2 \mathrm{~L}$ & Scraping marks & Scraping marks & $979-1-20456$ \\
\hline CIII & $979-1-20452-6$ & & & Bone & & & \\
\hline CIII & $979-1-20452-5$ & 10 & Juvenile & & & & \\
\hline CIII & $979-1-20453-1$ & 7 & Adult & Bone & $\begin{array}{l}\text { Buttonhole perforation; shaping; } \\
\text { polished through wear }\end{array}$ & & \\
\hline CIII & 979-1-20453-1bis & & & I3R & Scraping marks (+scraped root) & Scraping marks & \\
\hline CIII & 979-1-20453-1ter & & & $\mathrm{I} 2 \mathrm{R}$ & Scraping marks & Scraping marks & \\
\hline CIII & $979-1-20453-2$ & & & I3L & Scraping marks & $\begin{array}{l}\text { Scraping marks } \\
\text { (+scraped root) }\end{array}$ & \\
\hline CIII & $979-1-20453-3$ & & & $\mathrm{I} 2 \mathrm{~L}$ & Scraping marks & Scraping marks & \\
\hline CIII & $979-1-20453-4$ & & & $\mathrm{I} 1 \mathrm{~L}$ & Scraping marks & Scraping marks & \\
\hline CIII & $979-1-20453-5$ & & & $\mathrm{I} 1 \mathrm{R}$ & Scraping marks & Scraping marks & \\
\hline CIII & 979-1-20454-1 & 5 & Very old adult & $\mathrm{I} 3 \mathrm{~L}$ & Scraping marks & Scraping marks & \\
\hline CIII & $979-1-20454-2$ & & & $\mathrm{I} 1 \mathrm{~L}$ & Transverse incisions & Scraping marks & \\
\hline CIII & 979-1-20454-2bis & & & $\mathrm{I} 2 \mathrm{~L}$ & Scraping marks & Scraping marks & \\
\hline CIII & $979-1-20459$ & & & bone & $\begin{array}{l}\text { Transverse sawing; engraving; } \\
\text { polished through wear? }\end{array}$ & & \\
\hline CIII & 979-1-20455-1 & 8 & Very old adult & $\mathrm{I} 1 \mathrm{R}$ & Longitudinal cutmarks & & \\
\hline CIII & 979-1-20455-1bis & & & $\mathrm{I} 2 \mathrm{R}$ & Longitudinal cutmarks & & \\
\hline CIII & 979-1-20455-1ter & & & I3R & & Scraping marks & \\
\hline CIII & 979-1-20455-1qu & & & $\mathrm{I} 1 \mathrm{~L}$ & Longitudinal cutmarks & & \\
\hline CIII & 979-1-20455-1pent & & & $\mathrm{I} 2 \mathrm{~L}$ & Longitudinal cutmarks & & \\
\hline CIII & 979-1-20455-1six & & & $\mathrm{I} 3 \mathrm{~L}$ & & Scraping marks & \\
\hline CIII & $979-1-20455-2$ & & & bone & Shaping/polished through wear? & & \\
\hline CIII & 979-1-20456-2 & 2 & Very old adult & bone & $\begin{array}{l}\text { Transverse sawing; polished } \\
\text { through wear? }\end{array}$ & Transverse sawing & $979-1-20449 ?$ \\
\hline CIII & $979-1-20456-3$ & & & I3R & Scraping marks & $\begin{array}{l}\text { Scraping marks; oblique } \\
\text { and transverse incisions }\end{array}$ & $979-1-20449 ?$ \\
\hline CIII & $979-1-20456-4$ & & & $\mathrm{I} 1 \mathrm{R}$ & & Oblique incisions & 979-1-20449? \\
\hline CIII & $979-1-20456-5$ & & & $\mathrm{I} 2 \mathrm{R}$ & Scraping marks & Scraping marks & 979-1-20449? \\
\hline CIII & $979-1-20456-6$ & & & $\mathrm{I} 1 \mathrm{~L}$ & & Scraping marks & $979-1-20449 ?$ \\
\hline CIII & $979-1-20457-2$ & 1 & Very old adult & $\mathrm{I} 3 \mathrm{~L}$ & & Scraping marks & $979-1-20450 ?$ \\
\hline CIII & $979-1-20457-6$ & & & I1R & Scraping marks & Scraping marks & $979-1-20450 ?$ \\
\hline CIII & $979-1-20457-3$ & & & $\mathrm{I} 2 \mathrm{R}$ & Scraping marks & Scraping marks & $979-1-20450 ?$ \\
\hline CIII & $979-1-20457-4$ & 9 & Very old adult & $\mathrm{I} 2 \mathrm{R}$ & Scraping marks & & \\
\hline CIII & 979-1-20457-5 & & & $\mathrm{I} 1 \mathrm{R}$ & Scraping marks & & \\
\hline CIII & 979-1-20458-1 & 6 & Very old adult & $\mathrm{I} 2 \mathrm{~L}$ & & & \\
\hline CIII & 979-1-20458-1bis & & & $\mathrm{I} 3 \mathrm{~L}$ & & Scraping marks & \\
\hline CIII & 979-1-20458-2 & & & $\mathrm{I} 2 \mathrm{R}$ & Scraping marks & & \\
\hline CIII & $979-1-20453-7$ & & & bone & & & \\
\hline CIII & 979-1-20457-1 & 11 & Adult & $\mathrm{I} 2 \mathrm{R}$ & Scraping marks & & \\
\hline CIII & $979-1-20458-3$ & & & Root & Scraping marks & & \\
\hline CIII & $979-1-20452-3$ & & & Crown & & & \\
\hline CIII & $979-1-20452-4$ & & & Crown & & & \\
\hline CIII & $979-1-20453-6$ & & & Bone & & & \\
\hline CIII & $979-1-20454-3$ & & & Bone & & & \\
\hline CIII & 979-1-20456-1 & & & Bone & Transverse incisions? & & \\
\hline
\end{tabular}

on the mandible bone. Rather, the recurrent location of these striation marks suggests that the scraping was aimed at removing the connective tissue down to the alveolar bone, perhaps the better to reveal the teeth.

On three pieces, flint sawing marks and deep incisions can be observed on the horizontal branches of the mandibles, near the juncture between the two hemi-mandibles (Figs. 10 and 11). It would appear that there is a relationship between the saw marks and the deep incisions due to their identical anatomical position and the very similar nature of the actions involved, even though we cannot be sure that the objectives behind them were the same. The incisions, although deep, do not really affect the solidity of the pieces, while the act of sawing is destined to separate a piece in half. Some of the mandibles do not have these marks on them. However, as the exact location of these marks is a little variable, it is not possible to prove the complete absence of sawing on the fragmented pieces. On one of the mandibles, saw marks can be seen on the outer and inner surfaces of the bone. It can therefore be deduced that the sawing took place at the end of the operational sequence because, in order to access the internal surface on which it is observed, it would first have been necessary first to break the bone and modify the natural morphology of the mandible.

On one of the pieces, a deep almond-shaped groove has been made on the bone, the purpose of which is difficult to establish. This perforation shows no marks of use. On this same piece, significant shaping has modified the original structure of the anatomical element (Fig. 11).

Finally, one of the mandible bone fragments has an engraved design on it that is difficult to interpret (Fig. 12). Located between the broken edge and the sawn extremity of the object, two sets of hatching and some deeper marks combine to form an original design that is unique among the geometrical motifs found at Pastou cliff (Dachary, 2006). It could involve the very fragmentary remains of a figurative representation given that hatching was frequently 


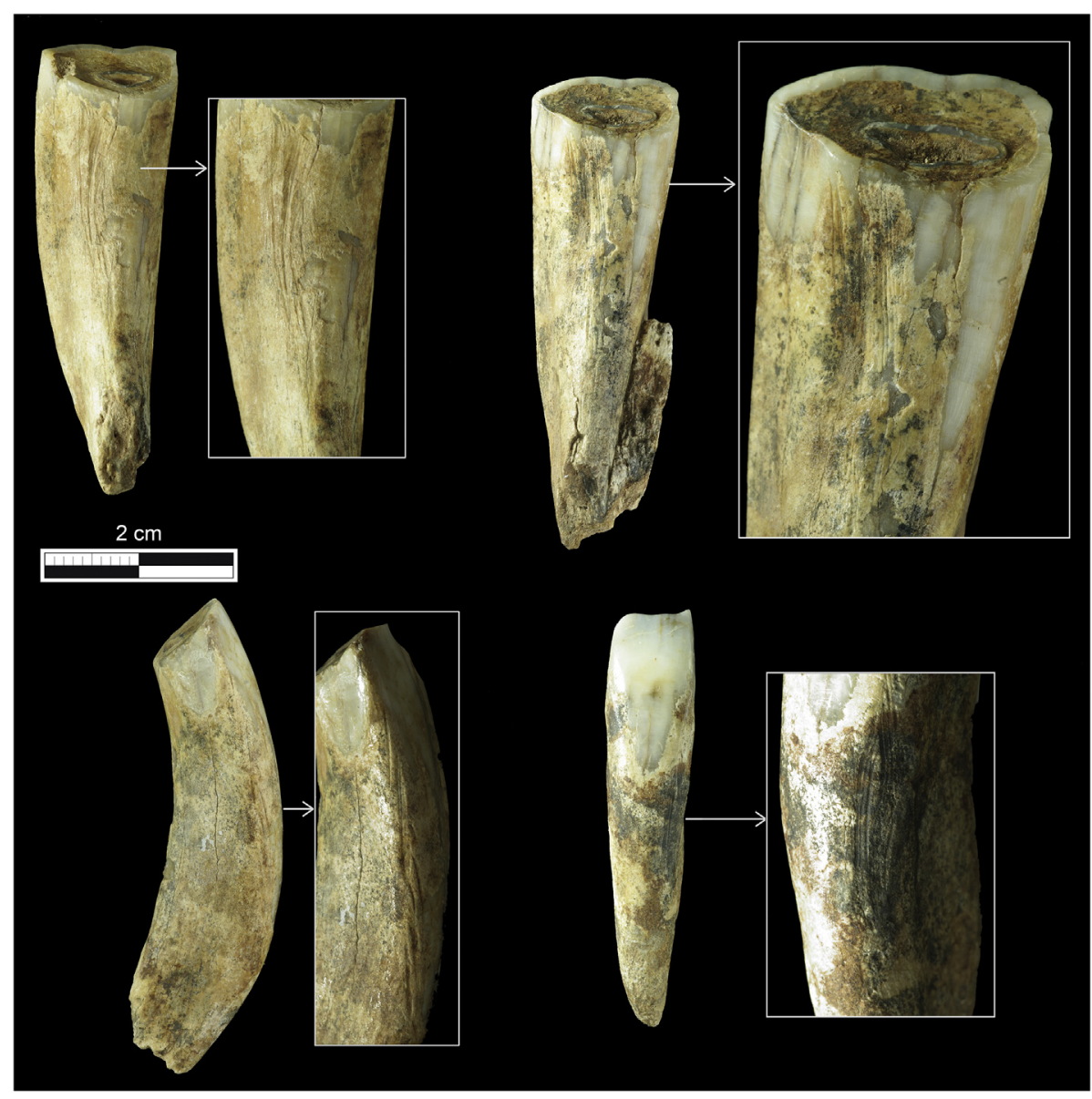

Fig. 9. Scraping marks.

used to depict manes, beards, and dewlaps. In any case, the use of a mandible bone in Upper Palaeolithic portable art is sufficiently exceptional (Paillet, 2014) for this piece, even in a very fragmentary state, to be of note.

\subsection{Initial review}

The value of this assemblage appears to lie both in the exceptional concentration of mandibles and the treatment of the bones.

It is difficult to view it as a simple waste deposit associated with standard technical production. On the other hand, this incisor and horse mandible assemblage could be considered an intentional deposit, because of its many particularities: an exceptional concentration in a restricted area of an archaeological site, a precise anatomical element (which one is generally not common in archaeological remains), a single taxon, old or very old individuals, special treatment, and a contextual association with horse representations.

The coherence of this assemblage indicates a significant investment of time. Indeed, the large number of horses counted in this restricted area raises the question of the acquisition of these old or very old animals. The "search" for particular objects implies a specific organization, whether it be the regular sorting of provisions, simple collection in an area of food waste, removal from carcasses, or the concerted and active hunting of certain individuals. The systematic scraping marks visible on these pieces, together with shaping, sawing, and engraving of designs are also evidence of a continued and concerted investment in the formation of this assemblage.

The selection of certain skeletal elements of the skulls of old horses hardly corresponds to a simple logic of optimization. Neither does the technical treatment of these pieces reflect any known economic objectives. The mandible deposit is a somewhat hybrid assemblage that we cannot imagine to be purely economic or symbolic. It does not exclusively involve artistic representations, body ornaments, or food waste, but perhaps all of these factors at once.

\section{Discussion}

\subsection{Comparisons}

We have found no strictly similar example to the assemblage from layer 4 of Duruthy. Accumulations of incisors from various ungulates, perforated and unperforated, have been observed in several archaeological sites of Late Upper Paleolithic in Quercy (Castel, 1999, 2003, 2010; Castel and Chauvière, 2014). However, in these sites, these accumulations are only perceptible through an overrepresentation of incisors in wildlife spectra and not, as in Duruthy, as remarkable spatial concentrations of anatomical elements. Comparisons are nonetheless possible with identical anatomical elements that have benefited from other unusual treatment.

In the Gravettian level of Trilobite cave in Arcy-sur-Cure (Yonne, France), six horse mandibles have been found with incisions on the 

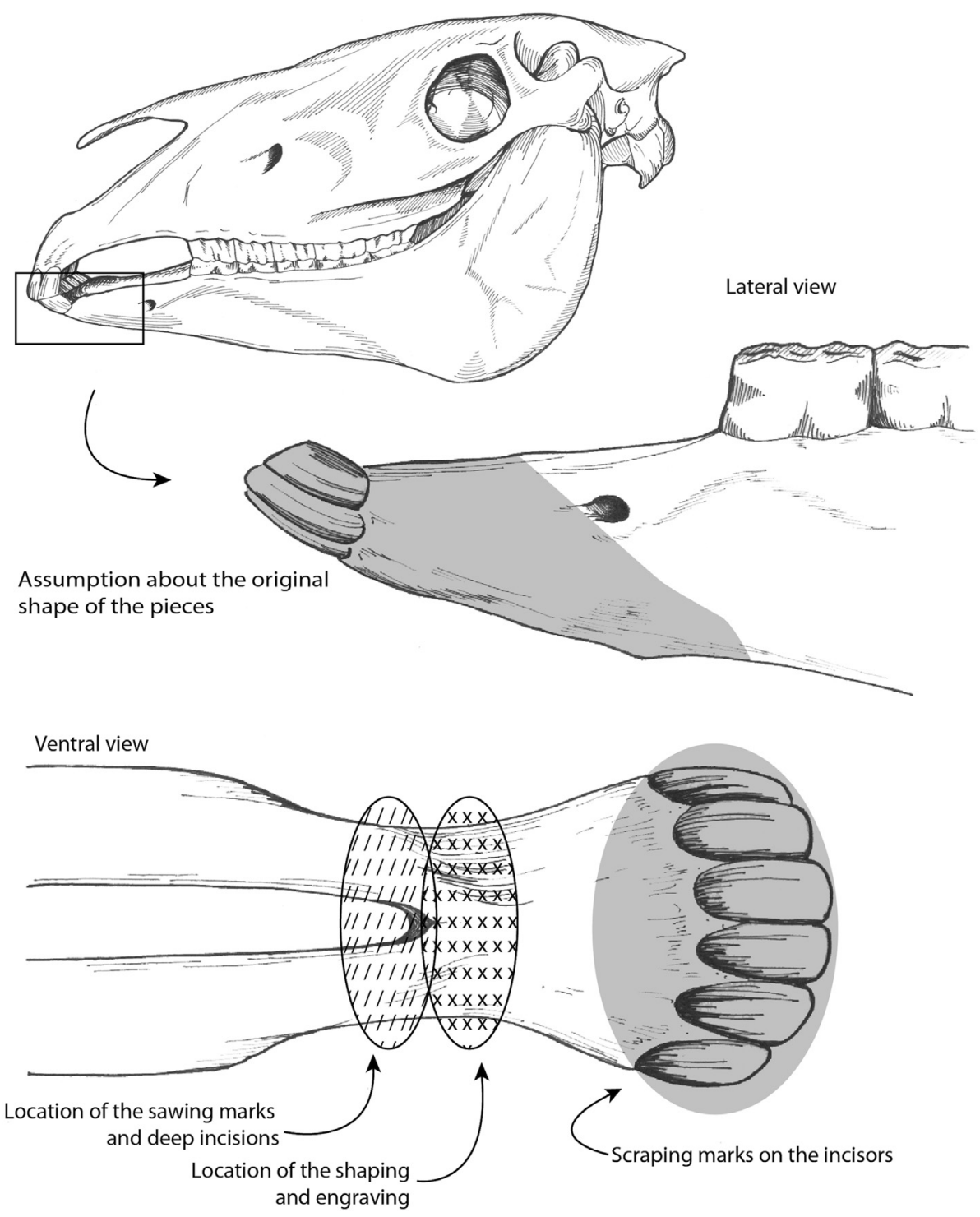

Fig. 10. Location of the marks.

mandibles (in about the same location as those from Duruthy rockshelter). No sawing marks, engravings, or scraping marks are observed on the teeth however (Goutas, 2013). The incisions, which are less regular than those at Duruthy, have been interpreted as butchery marks.

For the Middle and Upper Magdalenian, the points of comparison are more numerous:

- A horse mandible decorated with non-figurative motifs is reported in the Magdalenian assemblage sensu lato of the Vibraye collection from Laugerie-Basse (Dordogne, France; Paillet, 2014, p. 74-75);

- A horse mandible from the Magdalenian level of Kendrick's cave (England) also has a geometrical pattern (Sieveking, 1971). There are said to have been traces of ochre on the teeth at the time of discovery. A priori, this piece, which may have a contextual relationship with some human remains, has no sawing or scraping marks (Cook, 2013);

- The Pekárna-style spatulas found in the cave of the same name in Moravia (Czech Republic); in the Middle Magdalenian level of
Gazel cave (Aude, France); and perhaps in the Upper Magdalenian level of La Vache (Ariège, France) are also highly symbolic pieces that show the use of an adjacent part of the horse mandible and that exhibit figurative and non-figurative designs (Pétillon and Sacchi, 2013);

- A horse skull discovered in La Garma (Cantabria, Spain) is attributed to the late Magdalenian. It has clearly undergone special treatment with the removal of several elements including the maxillary, nasal, frontal, and parietal bones and the incisors, as well as the opening of the cerebral cavity (Arias et al., 2011, p. 40).

- At the Upper Magdalenian site of Oelknitz (Germany), two horse canines have been found with marks showing that they have been worked. One is an upper tooth found broken in its socket (Brasser, 2012, p. 181).

- The pointed and/or notched horse incisors from the Middle and Upper Franco-Spanish Magdalenian: La Viña (Asturias), Las Caldas (Asturias), La Garma (Cantabria), Bourrouilla (PyrénéesAtlantiques), Le Mas d'Azil (Ariège), Gourdan (Haute-Garonne), etc. (Chauvière, 2006; Sauvet et al., 2008; Mereau, 2012); 


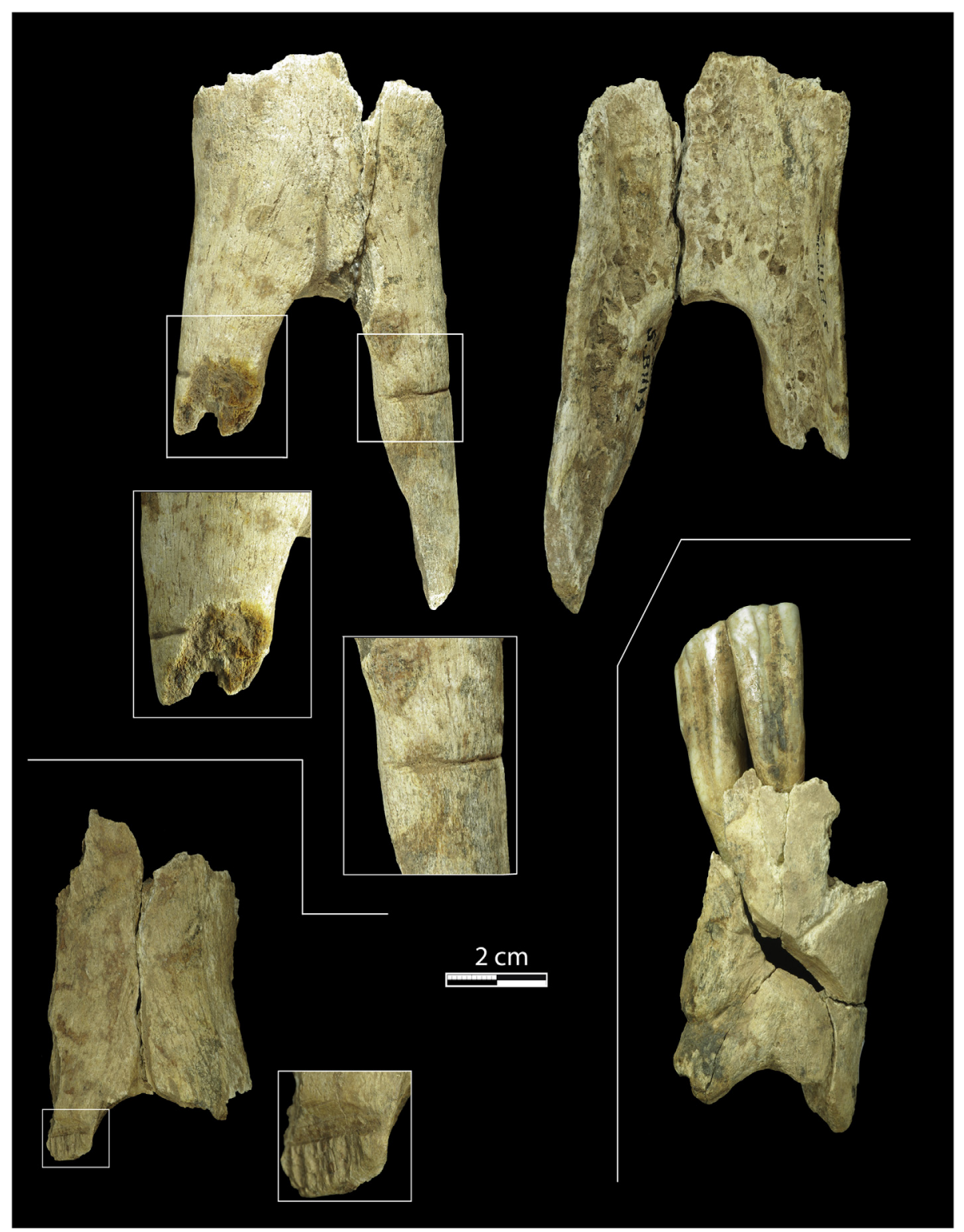

Fig. 11. Sawing marks, deep incisions, and perforation.

- The horse incisors engraved with geometrical designs on the lingual surface, dated from the early phase of the French Middle Magdalenian in Poitou (La Marche, Roc aux Sorciers, Grotte des Fadets, and Gaudry rockshelter) (Airvaux, 2001; Mazière, 2009). The large number of objects involved, the presence of incisions, and a special selection of individuals (young horses in this case) show some similarities with the objects of our study.

\subsection{The importance of teeth as body ornaments in Magdalenian} culture

Teeth have a consistently important role in Upper Palaeolithic body ornaments, particularly from the Magdalenian (Ladier and Welté, 1993, 1994; Poplin, 1983; Taborin, 1998, 2004; Vanhaeren and D'Errico, 2011; White, 2007 etc.), and the mandible assemblage discussed here could reflect this practice.

The teeth of ungulates (reindeer, but also red deer, ibex, and bovines) are frequently found with saw marks and sometimes conserved together as a set at Magdalenian sites (Desbrosse, 1972; Poplin, 1983). The anatomy of the horse being different to that of bovids and cervids (horse incisors being better attached and having stronger roots), the place of sawing must be adjusted to achieve the same goal, namely the recovery of the complete set of incisors.

At Duruthy it was perhaps a case of this same aim of recovering and conserving the sets of incisors, but applied to the horse. It is still necessary to establish the reason why this act has only been observed at Duruthy rockshelter, however, and why these sets of incisors have been accumulated there.

\subsection{The horse head in all its forms}

In parallel with the unique status of teeth, special treatment is accorded to the skull, particularly the horse skull, in the middle and upper phases of the Pyrenean Magdalenian. This treatment covers the whole "conceptual field" from representations of horse heads to a concern for the physical elements of a horse head (Delporte, 1990; Buisson et al., 1996, for example): 


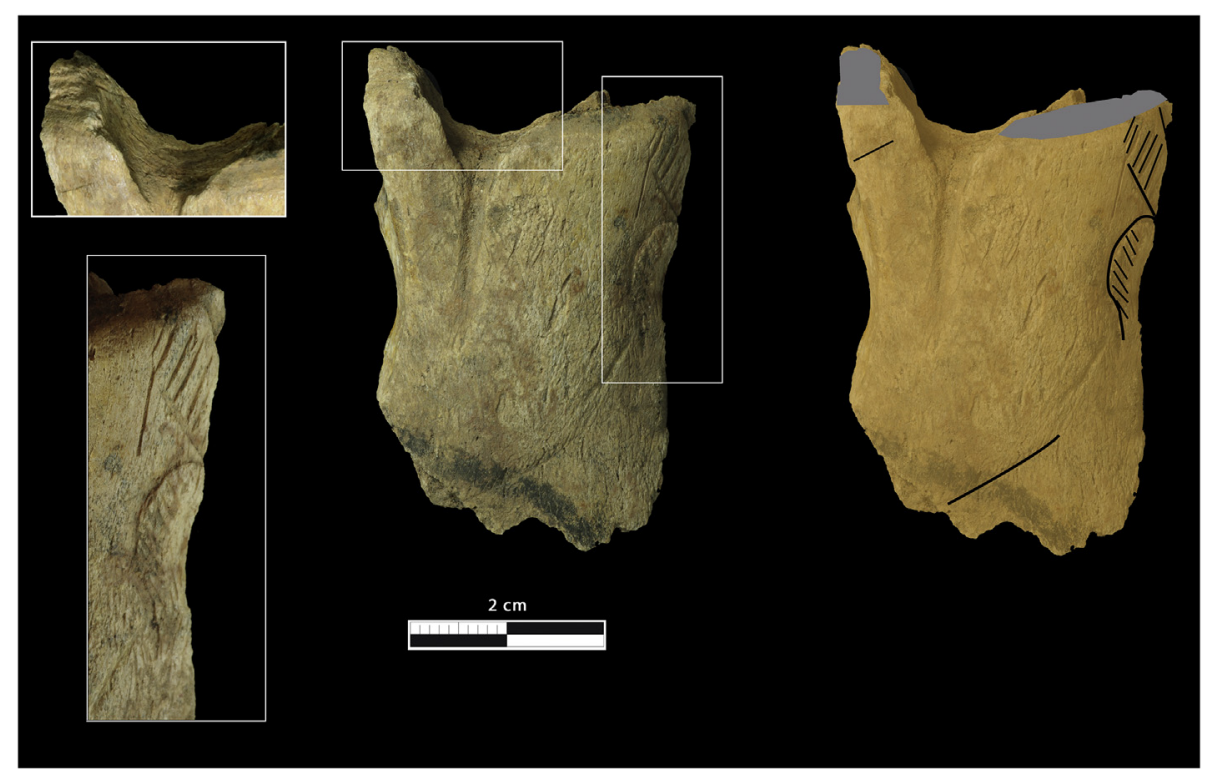

Fig. 12. Engraving on horse mandible bone fragment.

1/Sculptures (Isturitz and Duruthy), engravings, drawings, and paintings representing horse heads (Les Trois Frères, Le Portel, Niaux, Isturitz, etc.);

2/Sculptures of emaciated horse skulls (Mas d'Azil);

3/Contours découpés representing a horse head on a hyoid bone, itself from a horse head (Mas d'Azil, Le Portel, Enlène, Isturitz, etc.);

4/Modifications made to a horse skull (La Garma).

Duruthy lies at the heart of the questions raised by these transversal practices, part way between skull and representation, as horse mandibles are found there alongside sculptures of horses. Furthermore, the mandible deposit is itself a collection of bones from horse skulls, invested with a symbolic dimension, even if they have not been significantly modified. It was probably their very value as identifiable bones, teeth, and faunal remains that was sought. Furthermore, these pieces have undergone an exacerbation of some of their characteristics, the scraping marks on the teeth perhaps having been the result of an attempt to remove the connective tissue down to the alveolar bone to emphasize the teeth.

\section{An indication of animism in the Magdalenian?}

The mandible deposit of Duruthy does not seem purely economic or purely symbolic, and we thus have attempted to amend this discussion while avoiding a classic binary approach-symbolic versus economic-of the "role" attributed to horses during the middle and upper phases of the Pyrenean Magdalenian. We have thus preferred to explore the perspectives offered by an approach that involves doing away with the nature/culture dichotomy typical of naturalism in order to better glimpse at the Magdalenian systems of perception. In order to achieve this, we have tried to situate our research as closely as possible with recent advances in anthropology, in particular by drawing inspiration from Descola's Anthropology of Nature (2001, 2005, 2007, 2010). In his publication, Beyond Nature and Culture (2005), Descola presents the four ontologies he identifies in the world and underlines the fact that these are also the only four that are logically possible. They are based on the two main categories of experience that we can have of ourselves: we are corporal beings with a consciousness and an intentionality. Descola attributes humans with a consciousness of physicality and interiority. The choice that is offered to human groups is therefore that of focusing on the continuities or the discontinuities in physicality and interiority.

The four ontologies proposed by Descola can be briefly summarized as follows:

- Naturalism: Difference in interiorities and resemblance of physicalities.

- Analogism: Difference in interiorities and difference in physicalities.

- Totemism: Resemblance of interiorities and resemblance of physicalities.

- Animism: Resemblance of interiorities and difference in physicalities.

We suggest that the horse mandibles at Duruthy rockshelter could be an indication of animism in the Pyrenean Magdalenian. Descola (2005) defined animism as the application to non-humans of a human-like interiority together with the discontinuity of corporal physicalities. Depictions of an animist ontology therefore involve making visible a common interiority found in bodies with very different appearances (Descola, 2010).

The Duruthy mandibles fall within two Magdalenian practices: on one hand, the recovery of complete sets of ungulate incisors, and on the other hand, representations and modifications to horse skulls in the Pyrenees and Cantabrian region. A particular emphasis on the physical differences of animals can be observed in Magdalenian body ornaments. These body ornaments focus on specific distinctions, but beyond this simple observation, they appear particularly concerned with animal physicality in the manner of animism, in other words, in the particular physical features of existing animals that will determine their actions and behaviour in the world (carnivore canines, herbivore incisors, the claws of bird of prey, etc.).

The presence of the whole conceptual field of the horse head, between materiality and representation, could in turn indicate a search for interiority and for what may lie behind the face or the mask, for the head is the emblematic element of an individual and its identity and intentionality. However, in animism, depictions of 
the dialectic between interiority and physicality most often seem to take the relatively simple form of a play between costume and mask (in Amazonia and in the circumpolar regions in particular, Descola, 2007).

In animism, costumes and body ornaments that involve adding animal pieces to the human body reflect an interest in the physicality of an animal and its world (Descola, 2007) and a consideration for non-human perceptions (Taylor, 2010). These practices also underline the interchangeable and superficial dimension of physical attributes. In animism, the body is a garment and the garment (including body ornaments) is often a body to be adopted (Ingold, 2000). But if putting on a costume means accessing the physicality of an animal, putting on a mask means access its interiority (Descola, 2007). Adding an additional face to an existing one, just like removing its face or its head, return us to this same question of interiority, for in animism the face itself becomes a mask (Ingold, 2000).

The Duruthy horse mandibles might thus appear more related to the animist mode of identification. They also seem to show no direct bearing with any of the other three ontologies defined by Descola.

In naturalism, it is not through the body, but through the mind, that humans are distinguished from non-humans; bodies are subject to nature and are not distinguished by ways of life (as is the case in animism). Thus, naturalism tends to show the distinctive interior of each human being combined with the physical continuity of things in a space viewed as homogeneous (Descola, 2010). Representations of this kind are most often based on realistic characters portrayed in a realistic framework and hardly correspond to the gesture behind the Duruthy mandibles.

Analogism is based on a conception of the general discontinuity of interiorities and physicalities in which networks of correspondence allow for interpretation. It is therefore segments of the world and its systems of correspondence that are the focus of analogism (Descola, 2010); the correspondence between microcosms and macrocosms, pantheons, hierarchies, symmetries, etc. It would also therefore be difficult to find a clear place in this mode of identification for the gesture behind the Duruthy mandibles.

In the case of totemism, representations must lead one to see the deeper identity of humans and non-humans of the totemic class. This identity is partly internal because they have the same essence and origin. This identity is also physical, because they are made of the same substance, share the same structure, and have the same kind of temperament. Two kinds of representation seem very common in Australian totemism. Either the beings of the Dreamtime that are at the origin of a totemic class are represented without background, narration, or dynamism (Arnhem Land) to show that the world is limited to the bodies of these original beings. Or, an account of the actions of these beings is depicted in the exclusive form of the marks they have left on the landscape and thus without representing them directly (Central Desert), to show that the action of composing the totemic classes has been achieved (Descola, 2007, 2010).

Totemism does not therefore appear to be an ontology that is directly compatible with the Duruthy mandibles either. In totemism, life forms are set, unchanging, and rooted in the landscape. If the animal is represented, it has an established pictorial form, an inanimate and definitive posture because it is not in the world: it is the world (Ingold, 2000). This view therefore contrasts with the specific distinctions of animism, which involve a consideration of the individual (the analysis of the Duruthy mandibles suggests a selection of particularly old individuals) and a particular focus on ways of life and behaviour (the incisors of the Duruthy mandibles show the systematic scraping of teeth, the aim of which appears to have been to exacerbate certain anatomical features characteristic of the manner of life of the horse).
Totemism seems nonetheless difficult to set aside based on the examination of the Duruthy mandibles alone. Australian totemism has yielded little portable art that can be directly compared with Magdalenian portable art. Furthermore, a form of totemism (although not exactly the same as that defined by Descola) has repeatedly been evoked in reference to the parietal art of the Upper Palaeolithic (Reinach, 1903; Raphael, 1945; Laming-Emperaire, 1972; Testart, 2012, for example.). A comparative analysis of parietal art in relation to the totemic and animist ontologies therefore remains a priority.

In succeeding in demonstrating that the Magdalenian remains reflect an animist mode of identification, we could gain an understanding of the conceptual framework of Magdalenian societies. In the animist ontology, art and artisanery do not involve producing a work of art ex nihilo by imposing one's will on a neutral and inert "material." Rather, the artist seeks to bring out a form that is already suggested, for example, in a horse bone or a stone. What matters is the revealing (Ingold, 2000) of a particular physicality, through the designation or accentuation of distinctive attributes present in the "material" concerned. In the case of an animist ontology, the Magdalenian horse form could thus appear in the natural shape of a block of stone or simply emerge from an untouched bone: it could thus involve a sculpture, a hyoid bone, preserved incisors, or a collection of mandibles, some of which have barely been processed while others have been more so.

The Duruthy mandibles are currently a simple indication that paves the way for our understanding of the Magdalenian mode of identification. Achieving such an ambitious goal could only be envisaged after the review, free from any artificial opposition between nature and culture, of a representative collection (the largest possible) of archaeological remains from all areas of Magdalenian life (the treatment of the dead, parietal and mobiliary art, body ornaments, the treatment of animal carcasses etc.). The first results that we have been able to gain through a consideration of the anthropology of nature seem nonetheless to highlight the scientific value of this method in Palaeolithic archaeology and to encourage us to continue on this path.

\section{Acknowledgements}

This study was partially funded by the French Research Agency (ANR) in the framework of the MAGDATIS project (ANR 2011 BSH3 0005). We thank its coordinators (Jean-Marc Pétillon, Mathieu Langlais, Véronique Laroulandie and Sandrine Costamagno) for the help in the production of this paper. Our gratitude goes also to the Département des Landes, and especially Sylvie Tersen and Delphine Haro-Gabay, who alloweded us to study the archaeological remains from Duruthy rock shelter. The Service Régional de l'Archéologie, accepting to open the Robert Arambourou archives, allowed us to develop the historical aspect of this research. Thanks to Nathalie Fourment, Olivier Ferullo and Sandra Boussaguet. Thanks to Sarita Jannin for the English translation.

\section{References}

Airvaux, J., 2001. L'art préhistorique du Poitou-Charentes, sculptures et gravures des temps glaciaires. La Maison des roches, Paris.

Arambourou, R., 1962. Sculptures magdaléniennes découvertes à la grotte Duruthy, Sorde-l'Abbaye (Landes). L'Anthropologie 66, 457-468.

Arambourou, R., 1978. Le gisement préhistorique de Duruthy à Sorde-l'Abbaye (Landes). Bilan des recherches de 1958 à 1975. Société Préhistorique Française, Paris.

Arambourou, R., 1980. Les recherches de Préhistoire dans les Landes en 1978 et 1979. Bulletin de la Société de Borda, p. 11.

Arambourou, R., 1990. Préhistoire en Pays Basque Nord et Sud des Landes. Munibe 42, 91-96. 
Arambourou, R., Genet-Varcin, E., 1965. Nouvelle sépulture du Magdalénien final dans la grotte Duruthy à Sorde L'Abbaye (Landes). Annales de Paléontologie (Vertébrés) 51, 127-151.

Arias, P., Ontañón, R., Álvarez-Fernández, E., Cueto, M., Elorza, M., García-Moncó, C., Güth, A., Iriarte, M.-J., Teira, L.C., Zurro, D., 2011. Magdalenian floors in the Lower Gallery of La Garma. A preliminary report In: GaudzinskiWindheuser, S., Jöris, O., Sensburg, M., Street, M., Turner, E. (Eds.), Site-Internal Spatial Organization of Hunter-Gatherer Societies: Case Studies from the European Palaeolithic and Mesolithic. Verlag des Römisch-Germaniuschen Zentralmuseums, Mainz, pp. 31-51.

Bahn, P., 1982. Homme et cheval dans le quaternaire des Pays de l'Adour. In: Les Pays de l'Adour. Royaume du Cheval. Musée Pyrénéen de Lourdes/Musée National du Château de Pau, pp. 21-26.

Bignon, O., 2003. Diversité et exploitation des Equidés au Tardiglaciaire en Europe occidentale. Implications pour les stratégies de subsistance et les modes de vie au Magdalénien et à l'Azilien ancien du bassin parisien. Université Paris X (Thèse de Doctorat)

Brasser, M., 2012. Horse exploitation at the Late Upper Palaeolithic site of Oelknitz (Thuringia, Germany) with special reference to canine modifications. Quaternary International 252, 175-183.

Buisson, D., Fritz, C., Kandel, D., Pinçon, G., Sauvet, G., Tosello, G., 1996. Les contours découpés de têtes de chevaux et leur contribution à la connaissance du Magdalénien moyen. Antiquités nationales 28, 99-128.

Castel, J.-C., 1999. Comportements de subsistance au Solutréen et au Badegoulien d'après les faunes de Combe-Saunière (Dordogne) et du Cuzoul de vers (Lot). Université Bordeaux I. Thèse de doctorat.

Castel, J.-C., 2003. Économie de chasse et d'exploitation de l'animal au Cuzoul de Vers (Lot) au Solutréen et Badegoulien. Bulletin de la Société préhistorique Française 100 (1), 41-66.

Castel, J.-C., 2010. Comportements de subsistance au Solutréen et au Badegoulien d'après les faunes de Combe-Saunière (Dordogne) et du Cuzoul de vers (Lot). Editions universitaires européennes, Saarbrücken.

Castel, J.-C., Chauvière, F.-X., 2014. Du Pléniglaciaire au Tardiglaciaire en Quercy central: continuités, discontinuités dans l'exploitation du monde animal. In: Cretin, C., Castel, J.-C., Ferullo, O. (Eds.), Deuxième moitié et fin du Paléolithique supérieur. Pour une confrontation entre le modèle classique et les perceptions interdisciplinaires actuelles sur le thème des unités, continuités et discontinuités), XXVIIe Congrès Préhistorique de France, Bordeaux - Les Eyzies, 31 mai-5 juin 2010, Session F., Actes publiés sous la direction de Jaubert J., Fourment N., Depaepe P, vol. 2. Société Préhistorique Française, Paris, pp. 385-401.

Chauvière, F.-X., 2001. La collection Chaplain-Duparc des musées du Mans: nouveaux éléments d'interprétation pour la "sépulture Sorde 1" de Duruthy (Sorde l'Abbaye, Landes). Paléo 13, 89-110.

Chauvière, F.-X., 2006. Fonds commun et originalité du matériel dentaire travaillé dans le Magdalénien d'Arancou (Pyrénées-Atlantiques). In: Chauchat, C. (Ed.), Préhistoire du Bassin de l'Adour: bilans et perspectives, Colloque Izpegi, CNRS, Saint-Etienne de Baigorry (France), 19 janvier 2002. Saint-Etienne-de-Baïgorry, Edition Izpegi de Navarre, pp. 225-248.

Cook, J., 2013. Ice Age Art. Arrival of the Modern Mind. The British Museum press, London.

Dachary, M., 2006. Les Magdaléniens à Duruthy. Qui étaient-ils? Comment vivaientils? Catalogue d'exposition, Abbaye d'Arthous à Hastingues (7 octobre-10 décembre 2006). Conseil général des Landes, Centre Départemental du Patrimoine.

Dachary, M., 2002. Le Magdalénien des Pyrénées occidentales. Université de Paris X. Thèse de Doctorat.

Dachary, M., 2009. Une perception affinée du Magdalénien des Pyrénées occidentales à partir des travaux récents. In: Fullola, J.-M., Valdeyron, N. Langlais, M. (Eds.), Les Pyrénées et leurs marges durant le Tardiglaciaire. Mutations et filiations technoculturelles, évolutions paléo-environnementales, actes du XIVème colloque international d'archéologie de Puigcerda, novembre 2006, Hommages à Georges Laplace. Puigcerdà, Institut d'Estudis Ceretans, pp. $423-460$.

Delporte, H., 1990. L'image des animaux dans l'art préhistorique. Picard, Paris.

Desbrosse, R., 1972. Les dents incisées du Paléolithique. L'Anthropologie 76 (1-2), 135-140.

Descola, P., 2001. Leçon inaugurale au Collège de France, pour la chaire d'anthropologie de la nature. Collège de France, Paris.

Descola, P., 2005. Par-delà nature et culture. Gallimard, Bibliothèque des sciences humaines, Paris.

Descola, P., 2007. Compte rendu d'enseignement. Annuaire du Collège de France, pp. 2005-2006.

Descola, P., 2010. La Fabrique des images. Visions du monde et formes de la représentation. Somogy \& musee du quai Branly, Paris.

Goutas, N., 2013. Nouvelles données sur l'industrie osseuse des grottes du Renne et du Trilobite à Arcy-sur-Cure (Yonne, France): vers l'identification de nouveaux marqueurs techniques et culturels du Gravettien moyen à burins du Raysse. In: Bodu, P., Chehmana, L., Klaric, L., Mevel, L., Soriano, S., Teyssandier, N. (Eds.), Le Paléolithique supérieur ancien de l'Europe du Nord-Ouest. Réflexions et synthèses à partir d'un projet collectif de recherche sur le Paléolithique supérieur ancien du Bassin parisien, Séance de la Société préhistorique française, Musée de Sens (Yonne)-CEREP, 15-18 avril 2009. Société préhistorique française (Mémoire 56), Paris, pp. 89-115.
Guadelli, J.L., 1998. Détermination de l'âge des chevaux fossiles et établissement des classes d'âge. Paléo 10, 87-93.

Henry-Gambier, D., 2006. Les sépultures de Sorde-l'Abbaye (Landes). In: Dachary, M. (Ed.), Les Magdaléniens à Duruthy. Qui étaient-ils? Comment vivaient-ils? Catalogue d'exposition, Abbaye d'Arthous à Hastingues (7 octobre-10 décembre 2006). Conseil général des Landes, Centre Départemental du Patrimoine, pp. 67-73.

Ingold, T., 2000. The Perception of the Environment: Essays on Livelihood. Dwelling \& Skill, Routledge.

Ladier, E., Welté, A.-C., 1993. Les objets de parure de la vallée de l'Aveyron. Fontalès, abris de Bruniquel (Plantade, Lafaye, Gandil). Paléo 5, 281-317.

Ladier, E., Welté, A.-C., 1994. Bijoux de la préhistoire. La parure magdalénienne dans la vallée de l'Aveyron, Catalogue d'exposition des Muséum d'Histoire Naturelle de Montauban et de Toulouse. Mercuès, Publi-Offset.

Laming-Emperaire, A., 1972. Art rupestre et organisation sociale. Santander Symposium, pp. 65-82.

Lartet, L., Chaplain-Duparc, G., 1874a. Sur une sépulture des anciens Troglodytes des Pyrénées superposée à un foyer contenant des débris humains associés à des dents sculptées de Lion et d'Ours. Matériaux pour l'histoire primitive et naturelle de l'homme V, Xème année, 2ème série, pp. 101-167.

Lartet, L., Chaplain-Duparc, G., 1874b. Sur une sépulture des anciens Troglodytes des Pyrénées superposée à un foyer contenant des débris humains associés à des dents sculptées de Lion et d'Ours. Congrès international d'anthropologie et d'archéologie préhistoriques, Compte-rendu de la 7ème session, Stockholm, 1874. Kraus reprinte 1969 (1), 302-310.

Lartet, L., Chaplain-Duparc, G., 1874c. Une sépulture des anciens Troglodytes des Pyrénées, superposée à un foyer contenant des débris humains associés à des dents sculptées de lion et d'ours. Bulletin de la Société d'anthropologie de Paris 1 , pp. $516-525$.

Leroi-Gourhan, A., 1943. Evolution et techniques. L'homme et la matière. Editions Albin Michel, coll. Sciences d'aujourd'hui, Paris.

Levine, M.A., 1979. Archaeo-zoological Analysis of Some Upper Pleistocene Horse Bone Assemblages in Western Europe. University of Cambridge (Ph D. thesis).

Lyman, R.L., 1994. Vertebrate Taphonomy. Cambridge Manuals in Archaeology. Cambridge University Press, Cambridge.

Mazière, G., 2009. Les incisives de chevaux gravées. In: Pinçon, G. (Ed.), Le Roc-auxSorciers: art et parure du Magdalénien. RMN, Paris (Catalogues des collections). http://www.catalogue-roc-aux-sorciers.fr/html/12/collection/2_4_3.html.

Mereau, A.-L., 2012. Les dents animales perforées au Magdalénien. Nouvelles perspectives fonctionnelles. Etude de quatre sites pyrénéens: Isturitz, le Mas d'Azil, Arudy et Gourdan. Université de Paris I-Panthéon Sorbonne (Thèse de Doctorat).

Merlet, J.-C., 2007. À propos du signe barbelé dans l'art mobilier magdalénien. L'exemple d'Isturitz (Pyrénées-Atlantiques) et de Sorde-l'Abbaye (Landes). Archéologie des Pyrénées occidentales et des Landes 26, 21-32.

Müller, W., 2013. Le site magdalénien de Monruz, 3. Acquisition, traitement et consommation des ressources animales. Neuchâtel, Office du patrimoine et de l'archéologie (Archéologie neuchâteloise, 49).

Muylle, S., Simoens, P., Lauwers, H., 1996. Ageing horses by an examination of their incisor teeth: an (im)possible task? Veterinary Record 138, 295-301.

Nicks, B., Delfontaine, B., Claveau, C., Ferrari, S., Canart, B., Vandenheede, M., 2007. Accuracy of ageing horses by their dentition: results of a study on Belgian draft mares. Annales de Médecine Vétérinaire 151, 6-14.

Paillet, P., 2014. L'art des objets de la préhistoire. Laugerie-Basse et la collection du marquis Paul de Vibraye au Muséum national d'histoire naturelle. Errance, Arles.

Perlès, C., 1991. Economie des matières premières et économie du débitage: deux conceptions opposées ?. In: 25 ans d'études technologiques en préhistoire. Bilan et perspectives. Actes des $\mathrm{XI}^{\mathrm{e}}$ Rencontres Internationales d'Archéologie e d'Histoire d'Antibes, 18-20 octobre 1990. Juan-les-Pins, APDCA, pp. 35-45.

Pétillon, J.-M., Sacchi, D., 2013. Deux spatules du type Pekárna dans la grotte Gazel (Sallèles-Cabardès, Aude, France). In: de la Rasilla Vives, M. (Ed.), F. Javier Fortea Pérez. Universitatis Oventensis Magister. Estudios en homenaje. Universidad de Oviedo, Ménsula Ediciones, pp. 305-315.

Poplin, F., 1976. A propos du nombre de restes et du nombre d'individus dans les échantillons d'ossement. Cahiers du Centre de Recherches Préhistoriques 5 , 61-74.

Poplin, F., 1983. Incisives de Renne sciees du Magdalenien d'Europe occidentale. In: La faune et l'homme prehistorique. Dix etudes en hommage a Jean Bouchud réunies par François Poplin. Société Préhistorique Française, Paris, pp. 55-67 (Mémoire 16).

Raphael, M., 1945. Prehistoric Cave Paintings. Pantheon, Bollingen Series, № ${ }^{\circ}$, New York.

Reinach, S., 1903. L'art et la magie à propos des peintures et des gravures de l'âge du renne. Paris, L'Anthropologie 14, 257-266.

Sacchi, D., 1990. Bases objectives de la chronologie de l'art mobilier paléolithique dans les Pyrénées septentrionales. In: Clottes, J. (Ed.), L'art des objets au Paléolithique, tome 1: l'art mobilier et son contexte, colloque internationa Foix-le Mas d'Azil, 16-21 octobre 1987. Ministère de la Culture, Paris, pp. 13-30.

Sauvet, G., Fortea, J., Fritz, C., Tosello, G., 2008. Echanges culturels entre groupes humains paleolithiques entre 20.000 et 12.000 BP. Bulletin de la Societe Prehistorique Ariege-Pyrenees 63, 73-92.

Sieveking, G. de G., 1971. The Kendrick's Cave Mandible. British Museum Quarterly $35,230-250$ 
Taborin, Y., 1998. L'art des premières parures. In: Saco, D., Sauvet, G. (Eds.), Le propre de l'homme. Psychanalyse et préhistoire. Delachaux et Niestlé, Paris, pp. $123-150$.

Taborin, Y., 2004. Langage Sans Parole. La Parure Aux Temps Préhistoriques. La Maison des Roches, Paris.

Taylor, A.-C., 2010. Voir comme un autre. In: Descola, P. (Ed.), La Fabrique des images. Visions du monde et formes de la représentation. Somogy \& musee du quai Branly, Paris.

Testart, A., 2012. Avant l'histoire. L'évolution des sociétés, de Lascaux à Carnac. Gallimard, Paris.
Vanhaeren, M., D'Errico, F., 2011. L'émergence du corps paré. Objets corporels paléolithiques. Civilisations 59 (2), 59-86.

White, T.E., 1953. A method of calculating the dietary percentage of various food animals utilized by aboriginal peoples. American Antiquity 4, 396-398.

White, R., 2007. Systems of personal ornamentation in the Early Upper Palaeolithic: methodological challenges and new observations. In: Mellars, P., Boyle, K., BarYosef, O., Stringer, C. (Eds.), Rethinking the Human Revolution: New Behavioural and Biological Perspectives on the Origin and Dispersal of Modern Humans. McDonald Institute for Archaeological Research, Cambridge, UK, pp. 287-302. 